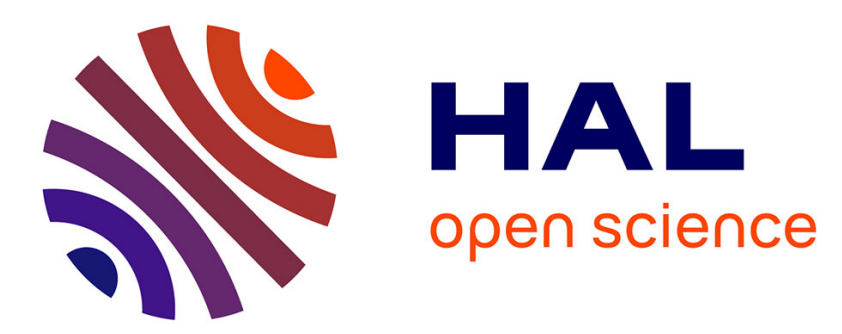

\title{
Atmosphere Controlled Roller Hearth Kiln for High Performance Mn-Zn Ferrites
}

S. Kijima, K. Arie, K. Gotoh, S. Nakashima, H. Kobiki, T. Kawano, N. Soga, S. Gotoh

\section{- To cite this version:}

S. Kijima, K. Arie, K. Gotoh, S. Nakashima, H. Kobiki, et al.. Atmosphere Controlled Roller Hearth Kiln for High Performance Mn-Zn Ferrites. Journal de Physique IV Proceedings, 1997, 07 (C1), pp.C1-65-C1-66. 10.1051/jp4:1997113 . jpa-00254772

\section{HAL Id: jpa-00254772 https://hal.science/jpa-00254772}

Submitted on 1 Jan 1997

HAL is a multi-disciplinary open access archive for the deposit and dissemination of scientific research documents, whether they are published or not. The documents may come from teaching and research institutions in France or abroad, or from public or private research centers.
L'archive ouverte pluridisciplinaire HAL, est destinée au dépôt et à la diffusion de documents scientifiques de niveau recherche, publiés ou non, émanant des établissements d'enseignement et de recherche français ou étrangers, des laboratoires publics ou privés. 


\title{
Atmosphere Controlled Roller Hearth Kiln for High Performance Mn-Zn Ferrites
}

\author{
S. Kijima, K. Arie, K. Gotoh, S. Nakashima, H. Kobiki*, T. Kawano*, N. Soga* and S. Gotoh* \\ Mizushima Factory, Kawatetsu Ferrite Corp., 1 Kawasaki-dori, Mizushima, Kurashiki 712, Japan \\ * Technical Research Lab., Kawasaki Steel Corp., I Kawasaki-cho, Chuo-ku, Chiba 260, Japan
}

\begin{abstract}
A new roller hearth kiln(RHK) has been developed, which satisfies not only the highest quality of $\mathrm{Mn}-\mathrm{Zn}$ ferrites, but also large quantity of production. Using the RHK (the length is $50 \mathrm{~m}$ ), the total sintering time is reduced to less than 11 hours, that is shorter than the half of the case of pusher kiln. Then the productive capacity of the RHK achieved 100 ton per month. Moreover, the control of oxygen content during sintering and the subsequently cooling is performed precisely, so that two different types of $\mathrm{Mn}-\mathrm{Zn}$ ferrite, i.e. high-permeability and low power loss materials, can be sintered simultaneously in the RHK. The electromagnetic properties of these materials reach to the highest level in mass production. This paper describes the basic structure and the characteristics of the new RHK, and shows the magnetic properties of Mn- $\mathrm{Zn}$ ferrites which are sintered by the RHK.
\end{abstract}

\section{INTRODUCTION}

In the manufacturing processes of $\mathrm{Mn}-\mathrm{Zn}$ ferrites, sintering is the most important for the magnetic properties of products. Especialy, initial permeability ( $\mu$ i) and power loss (Pc) are quite sensitive to temperature and oxygen content, however, as well as better performance, higher productivity, i.e. lower cost, is also required. Three types of kiln are commonly used for Mn-Zn ferrites, i.e. batch kiln(BK), continuous pusher kiln(PK), and continuous roller hearth kiln(RHK). RHK has the largest capacity of production, but is hardly possible to control the sintering conditions, particularly the oxygen concentration. BK and/or PK are therefore usually used for high quality $\mathrm{Mn}-\mathrm{Zn}$ ferrites[1][2]. But these types of kiln have reached the limit of productive ability. The authors developed three RHKs in Kawatetsu Ferrite Corporation, and the third one attains our purpose to obtain high quality and large productivity in mass production of $\mathrm{Mn}-\mathrm{Zn}$ ferrites. We will report the newly developed RHK.

\section{CHARACTERISTICS OF THE NEW RHK}

The kiln is divided into four zones as shown in Fig.1. (1) The pre-sintering zone for perfect decarbonization is located in the first zone so that the cores can be sintered more rapidly afterward. This zone is 10 meters long and is separated from the sintering kiln in order that no organic gases from the binder flow into the next zone. Because of the pre-sintering zone, very large cores e.g. R128 (OD=128, ID=96, H=30mm) can be sintered. (2) In the heating zone, direct-gas-firing both above and beneath the refractory boards is utilized to obtain a greater heating rate. At a test running, the maximum heating rate reached to $1800^{\circ} \mathrm{C}$ per hour. (3) In the 3rd zone of the kiln, the maximum sintering temperature is kept for a relatively long time by the effect of shortening the heating and cooling zones. (4) In the cooling zone, to accelerate the cooling rate, the cross section of the zone is made smaller than the other parts of the kiln.

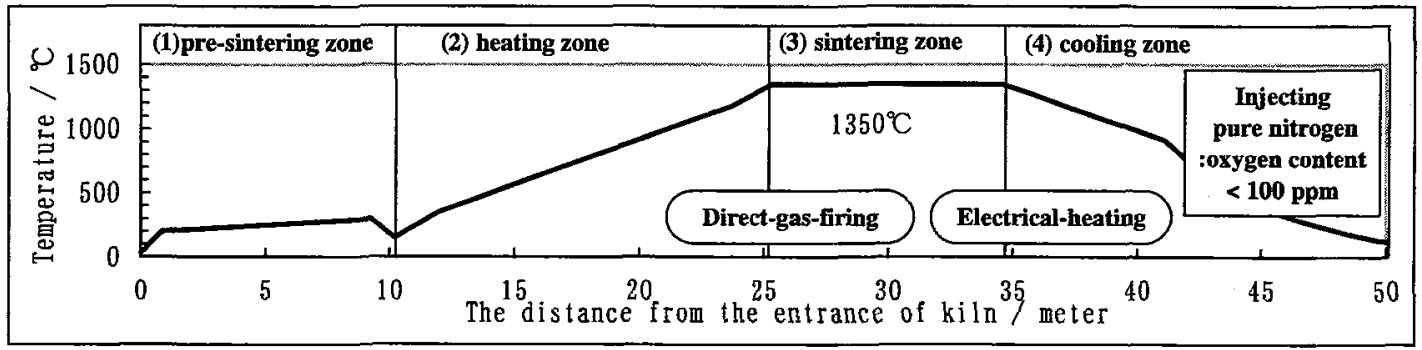

Fig. 1 The formation of the RHK and the sintering profile 
The direct-gas-firing and the resulting large amount of gas flow lead to the homogeneous temperature distribution in cores stacked on the refractory plates moving on ceramic rollers. Then the homogeneity and the long sintering zone provide the uniform electromagnetic properties of cores, for example, the dispersion of $\mu \mathrm{i}$ of the cores is obtained within $10 \%$. The control of oxygen content and temperature during sintering and the subsequently cooling is precisely performed by electric heating from the end of the sintering zone, since electric heating makes the atmosphere more stable than direct-gas -firing. The narrow aperture of the cooling zone contributes remarkably to decrease of oxygen concentration to about 100 parts per million with also the seal of the roller-holes. As a result, it enables to optimize the relation between temperature and oxygen content on the phase diagram of $\mathrm{Mn}-\mathrm{Zn}$ ferrite.

\section{THE MAGNETIC PROPERTIES OF Mn-Zn FERRITES SINTERED BY THE RHK}

The lowest Pc material, MB4, in mass production is shown in Fig. 2 as compared with the conventional material, MB3. The Pc of MB4 is $250 \mathrm{~kW} \cdot \mathrm{m}^{-3}$ at $100 \mathrm{kHz}, 200 \mathrm{mT}$ and $90^{\circ} \mathrm{C}$. The various high- $\mu$ i materials are shown in Fig. 3 . The highest $\mu$ i is 10000 (MA100) at $23{ }^{\circ} \mathrm{C}$. These two types of Mn-Zn ferrite can be sintered simultaneously in the RHK, and it shows the kiln to be an epoch-making one in mass production of $\mathrm{Mn}-\mathrm{Zn}$ ferrites.

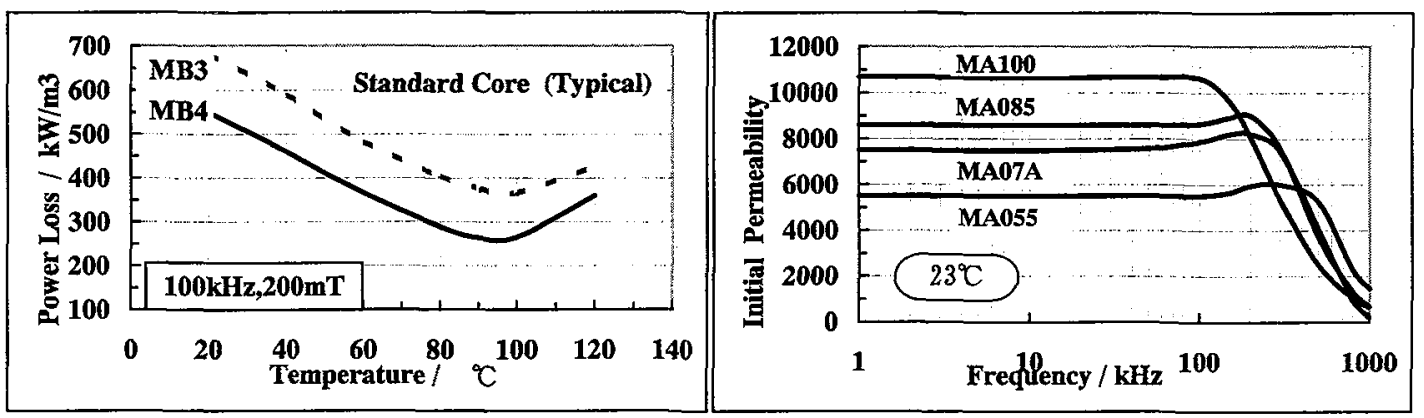

Fig.2 Temperature dependence of power loss for MB4 and MB3. Fig.3 Frequency dependence of $\mu$ i for various high- $\mu$ i materials.

\section{DISCUSSION : Comparison with PK}

In general, the most important difference between RHK and PK is the rate of heating and cooling, which influence both the productivity and the magnetic properties of products. For example, the $\mu$ i value increases with increasing the sintering density determined by the rate of heating[3]. There are two reasons for the difference of the rate. One is the heat capacity of the moving refractory plates. The used plate in PK is 5 times as heavy as that in RHK. Another is the ability of pushing with oil-cylinders. However, the problem of how to prolong the life time of the refractory plate arises from the higher rate of heating and cooling in RHK. The authors have been developing refractory plates which have resistance to rapid heat cycle.

In mass production using RHK, the accident of the roller destruction is very serious. If an accident happens, the operation should be stopped for 2 or 3 days. In order to prevent from such an accident, (1) the material of ceramic rollers in the high temperature region have been exchanged into silicon carbide, and (2) the sensing system has been developed which can warn us of only one broken roller.

\section{CONCLUSION}

The total sintering time of a new RHK is minimized less than 11 hours, which is shorter than half the time in the case of PK. The productive capacity in this RHK ( 50 meters long ) thereby achieved 100 tons per month. Two different types of $\mathrm{Mn}-\mathrm{Zn}$ ferrite, that is, high- $\mu \mathrm{i}$ and low-Pc materials, can be sintered simultaneously in the RHK. The $\mu \mathrm{i}$ of high$\mu$ i material reaches 10000 , and the Pc of low-Pc material is reduced to $250 \mathrm{~kW} \cdot \mathrm{m}^{-3}$ at $100 \mathrm{kHz}, 200 \mathrm{mT}$ and $90{ }^{\circ} \mathrm{C}$.

\section{Acknowledgments}

The authors are grateful to $\mathrm{H}$. Oshima of manager of NORITAKE CO., LIMITED and his staffs for the contribution to the development of the RHK.

\section{References}

[1]K. Okutani, "FERRITE", p.56-63,(1988)

[2]E. Roess, Proc. of ICF-5, India, (1989) pp129-136.

[3]K. Okutani, "Development of the Low Power Loss Ferrite for Switching Power Supply" 4th-ICF, San Francisco,(1984) 